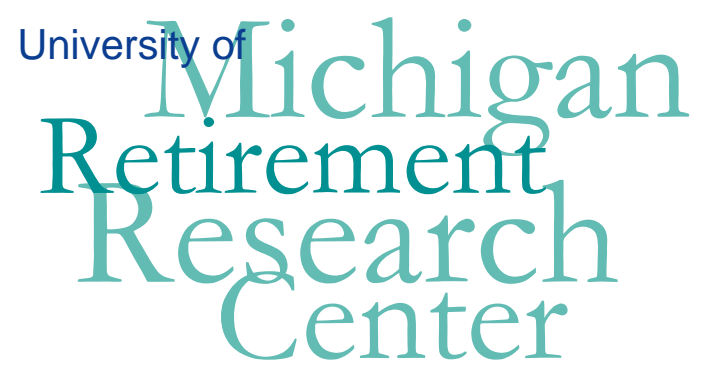

Working Paper

WP 2009-208

\title{
Income, Material Hardship, and the Use of Public Programs among the Elderly
}

\author{
Helen Levy
}

\begin{tabular}{|l|l|l|}
\hline $\mathrm{M}$ & $\mathrm{R}$ \\
\hline $\mathrm{R}$ & $\mathrm{C}$ & \\
\hline
\end{tabular}$\quad$ Project \#: UM09-14 



\title{
Income, Material Hardship, and the Use of Public Programs among the Elderly
}

\author{
Helen Levy \\ University of Michigan
}

September 2009

\author{
Michigan Retirement Research Center \\ University of Michigan \\ P.O. Box 1248 \\ Ann Arbor, MI 48104 \\ http://www.mrrc.isr.umich.edu/ \\ (734) 615-0422
}

\section{Acknowledgements}

This work was supported by a grant from the Social Security Administration through the Michigan Retirement Research Center (Grant \# 10-M-98362-5-01). The findings and conclusions expressed are solely those of the author and do not represent the views of the Social Security Administration, any agency of the Federal government, or the Michigan Retirement Research Center.

Regents of the University of Michigan

Julia Donovan Darrow, Ann Arbor; Laurence B. Deitch, Bingham Farms; Denise Ilitch, Bingham Farms; Olivia P. Maynard, Goodrich; Andrea Fischer Newman, Ann Arbor; Andrew C. Richner, Grosse Pointe Park; S. Martin Taylor, Gross Pointe Farms; Katherine E. White, Ann Arbor; Mary Sue Coleman, ex officio 


\title{
Income, Material Hardship, and the Use of Public Programs among the Elderly
}

\begin{abstract}
I use data from the 2006 Health and Retirement Study to analyze the determinants of material hardship among individuals ages 65 and older. Ten percent of the elderly report hardship defined here as cutting back on food or medications because of cost - in 2006. Although hardship is more likely for poorer individuals and, to some extent, for recipients of public transfer programs (Medicaid, Food Stamps, and/or Supplemental Security Income), the majority of those experiencing hardship are not poor and do not participate in these programs. In multivariate models, I find that self-reported health and activity limitations are significant predictors of hardship.
\end{abstract}




\section{Introduction}

Social Security has enjoyed great success at reducing poverty and promoting independence among the elderly (Engelhardt, Gruber, and Perry 2005; Engelhardt and Gruber 2006). Indeed, the poverty rate among the elderly is currently estimated at 9.7 percent, lower than for children or for working-age adults (DeNavas-Walt, Proctor and Smith 2009). The official poverty rate has been criticized on a number of grounds, however (Citro and Michael 1995), some of which disproportionately affect the elderly. For example, one criticism of the official poverty measure is that it does not take into account the burden of high out-of-pocket medical spending, which is much more likely to be a problem for elderly households (Short and Garner, 2002). Indeed, Census Bureau estimates using an alternative poverty measure proposed by the National Academy of Sciences to address many of these criticisms yield elderly poverty rates that are approximately twice the current official measure. ${ }^{1}$ These disputes over measurement and the widely different estimates they imply mean that poverty is an imperfect metric for evaluating the economic well-being of the elderly.

An alternative approach to evaluating the economic well-being of the elderly is to analyze material hardship directly. This approach has been applied to the non-elderly population, particularly to single-mother families and former welfare recipients (Mayer and Jencks 1989; Rector, Johnson and Youssef 1999; Danziger, Corcoran, Danziger and Heflin 2000; Meyer and Sullivan 2003; She and Livermore 2007; Sullivan, Danziger, and Turner 2008), but much less work has analyzed hardship among the elderly - perhaps because of their lower rates of official poverty. In this paper, I use data from the 2006 Health and Retirement Study to document

\footnotetext{
${ }^{1}$ U.S. Bureau of the Census; tabulations available at $h \mathrm{ttp}: / / \mathrm{www} . c e n s u s . g o v / \mathrm{hhes} / \mathrm{www} / \mathrm{povmeas} / \mathrm{tables} . \mathrm{html}$. Another proposed measure of poverty based on data from the Luxembourg Income Study would also yield higher poverty rates for the elderly (Brady 2004). Butrica, Murphy and Zedlewski (2008) demonstrate that a range of alternative measures of poverty yield higher poverty rates for the elderly.
} 
patterns of material hardship among the elderly. Hardship is defined here as cutting back on food or medications because of cost; ten percent of elderly reported one or both of these hardships in 2006. I estimate multivariate models predicting hardship as a function of income and other characteristics, including health and cognition, in order to paint a fuller picture of why older individuals - including some with quite high incomes - experience hardship. I also estimate the relationship between income, hardship, and use of three means-tested transfer programs: Food Stamps, Medicaid, and Supplemental Security Income (SSI). ${ }^{2}$

I find that while hardship is more likely among poor individuals and, to some extent, among poor individuals who are already users of transfer programs, the majority of the elderly experiencing hardship are neither poor nor using any of these programs. In multivariate models, health status is a highly significant predictor of hardship: individuals in worse self-reported health or who report more limitations on physical activity are much more likely to experience hardship. This result holds whether or not income is included as a control in the models and is also robust to the inclusion of individual fixed effects.

These findings have important implications for public policy. First, since most of the elderly experiencing hardship are, in fact, not poor and therefore not eligible for means-tested transfer programs, increasing outreach with the goal of enrolling more eligible elderly in these programs has limited potential to reduce hardship. Similar logic suggests that while increasing benefit levels might reduce hardship among those who are already receiving benefits, the potential to reduce hardship by increasing benefits is limited since transfer program recipients make up only about one-quarter of the elderly who experience hardship. Second, the importance of poor health in predicting hardship supports the view implicit in the criticisms of the official

\footnotetext{
${ }^{2}$ I do not consider the use of the Low-Income Subsidy associated with Medicare Part D because there is evidence that it is badly under-reported in survey data (Levy and Weir 2007).
} 
poverty measure that high medical spending may effectively reduce the resources available to some apparently high-income households, placing them at risk of hardship. One way to address this problem directly - regardless of any methodological changes in the measurement of poverty - would be for Medicaid and SSI to deduct some or all out-of-pocket medical spending from countable income in determining eligibility for elderly beneficiaries, as the Food Stamp program currently does for applicants ages 60 and older.

\section{Previous Research}

Several different strands in the literature provide important background for this analysis.

The first consists of studies analyzing the adequacy or optimality of retirement savings. A traditional approach to assessing the adequacy of retirement savings is to compare the income stream that would result from annuitizing wealth at the time of retirement to pre-retirement income (see, for example, Mitchell and Moore 1998, or the review in Vanderhei 2004). Retirement wealth is considered adequate if it yields an income stream that is not too much below what income was before retirement - regardless of how low this level may be. More recently, economists have noted that it is smooth consumption, rather than income, that reflects optimality and a number of papers test this proposition (Scholz, Shesadri and Khitatrakun 2006; Hurd and Rohwedder 2006a; Skinner 2007; Hurd and Rohwedder 2008a; Hurd and Rohwedder 2008b). Again, the focus here is on smoothness over time, rather than on the level of consumption; in particular, very low levels of consumption (so low as to result in food insecurity with hunger, for example) are not inconsistent with optimality in the economic sense.

A second relevant set of papers focuses on poverty among the elderly. Some of these extend the traditional approach to the adequacy of retirement wealth by comparing annuitized income streams to the poverty level; others compare actual income to the poverty level, while 
still others compare actual consumption to the poverty level (Hungerford 2001; Haveman, Holden, Wilson and Wolfe 2003; Haveman, Holden, Wolfe and Sherlund 2006; Haveman, Holden, Wolfe and Romanov 2007; Love, Smith and McNair 2008; Johnson and Mermin 2009; An important subset of these papers focuses on the high rate of poverty among elderly widows (Bound, Duncan, Laren and Oleinick 1991; McGarry 1995; Weir and Willis 2000; Zick and Holden 2000; Sevak, Weir, and Willis 2003/2004; McGarry and Schoeni 2005; Gillen and Kim 2009).

Third, there is a literature on economic well-being that focuses on material hardship rather than the level of income or consumption as the primary outcome of interest. Material hardship is operationalized in many different ways, depending on the population studied and the available data; overviews of different measures of hardship are provided by Federman et al. (1996), Beverly (2000), and Oullette et al. (2004). This strand in the modern literature originates with Mayer and Jencks (1989), who emphasize that poverty and material need are different outcomes and that reducing both are (or at least should be) distinct goals of public policy. A number of papers have built on this insight by estimating the determinants of material hardship. These studies differ in the extent to which they focus on the question of whether income versus consumption is a better predictor of hardship (Meyer and Sullivan 2003; Charles, Danziger, Pounder and Schoeni 2006) or whether they focus more generally on other predictors such as health (She and Livermore 2007; Sullivan, Danziger and Taylor 2008). Only one of these studies (Charles et al. 2006) focuses on the elderly.

Finally, several studies have analyzed the determinants of the two outcomes that are treated as measures of hardship in the current analysis - food or medication cutbacks - without making a connection to the larger literature on poverty and economic hardship. Lee and 
Frongillo (2001), using data from the Third National Health and Nutrition Examination Survey (1988-94) and a much smaller 1994 survey of the elderly in New York State find that low income, functional limitations, Hispanic ethnicity, younger age, and use of Food Stamps significantly predict food insecurity among the elderly. Steinman, Sands and Covinsky (2001) use data on the approximately 5,000 respondents ages 70 and older in the 1995/1996 wave of the HRS (the so-called "AHEAD" cohort) who regularly use prescription drugs to look at medication restriction among seniors. Among the 1,911 of these who have no drug coverage, Steinman et al. (2001) find that poor health, non-white race/ethnicity, low education, low income, and high out-of-pocket drug costs are all significant predictors of medication restrictions. Piette, Heisler, and Wagner (2004) and Heisler, Wagner, and Piette (2005) use data on approximately 4,000 individuals ages 50 and older with chronic illness to analyze the determinants of medication restrictions; they find that younger age, lower income, and higher out-of-pocket costs all significantly predict restrictions.

This analysis extends these studies (Lee and Frongillo 2001; Stein et al. 2001; Piette et al. 2004; and Heisler et al. 2005) by (1) looking at both types of cutbacks (medications and food) in a common empirical framework (2) linking the results to the more general literature on poverty (3) using more recent data (4) including more covariates and, in particular, more flexible controls for family income and (5) estimating individual fixed effects models.

\section{Data}

Data for the analysis come from the Health and Retirement Study, a longitudinal study that has interviewed older adults since 1992. Most analyses in this paper use data from the 2006 wave, and some use data from the 2004 wave of HRS as well. The 2006 wave of the survey includes 18,469 respondents who are representative of the US population ages 53 and older; I 
focus on the 10,900 respondents who are ages 65 and older. All statistics except for unweighted sample sizes are estimated using the HRS respondent-level sampling weights.

The HRS includes three yes/no questions that I use as measures of material hardship:

1. (Since your last interview/in the last two years), have you always had enough money to buy the food you need?

2. At any time (since your last interview/in the last two years), have you skipped meals or eaten less than you felt you should because there was not enough food in the house? [Asked only if response to question 1 is "yes."]

3. At any time (since your last interview/in the last two years) have you ended up taking less medication than was prescribed for you because of the cost?

I will refer to these different measures as food cutback, skipped meals, and medication cutback, respectively. I consider individuals who report any of them as experiencing hardship.

The HRS also includes data on respondent income, health, physical ability, cognition, and demographic characteristics. The explanatory variables in the analysis include:

Family income relative to the poverty threshold: I rely on the imputed version of this variable from the RAND HRS data file (Version I, March 2009). A comparison of poverty rates among the elderly and near-elderly using this variable shows that they benchmark reasonably well to poverty rates for a similarly defined sample using data from the March 2006 Current Population Survey. ${ }^{3}$

Health: Respondents report their assessment of their own overall health as excellent, very good, good, fair, or poor.

\footnotetext{
${ }^{3}$ Poverty rates for individuals ages 53-64 are 8.1 percent in HRS and 8.6 percent in CPS; for individuals ages 65 and older, 7.4 percent in HRS and 10.1 percent in CPS.
} 
Physical limitations: The HRS asks respondents about whether they have difficulty because of a health problem with 12 different activities: walking several blocks, jogging a mile, walking a mile, sitting for two hours, getting up from a chair, climbing several flights of stairs, climbing a single flight of stairs, stooping, raising arms about shoulder level, pulling or pushing large objects (the size of a living room chair), lifting or carrying weights over ten pounds (like a heavy bag of groceries), and picking up a dime from table. Following Fonda and Herzog (2004), I create an index of physical limitations by summing the number of positive responses to these items. The index takes on values from 0 (no limitations; healthiest) to 12 (most limitations; sickest).

Cognitive ability: In the HRS core survey, interviewers read a list of ten words to respondents, who then recall as many words as they can. They are asked to recall the words immediately after hearing the list and also several minutes later. I use the sum of these from the 2006 survey, ranging from 0 to 20 , as one indicator of cognitive ability. I also use respondents' scores on the "Serial Sevens" test, in which respondents are asked to count backward from 100 by sevens. The score is the number of correct subtractions (up to 4). Many respondents who have difficulty with these tasks refuse to complete them; I categorize those with missing data (about 15 percent for word recall and seven percent for Serial Sevens) into the lowest performance category on each these cognitive tests. Much more detail on the HRS cognition measures is available in Ofstedal, Fisher, and Herzog (2005).

Program use: I create dummy variables reflecting participation in three means-tested transfer programs: Medicaid, SSI, and Food Stamps. The Medicaid dummy indicates whether the individual reports Medicaid coverage at the time of the survey. The SSI and Food Stamp 
dummies indicate whether the respondent and/or spouse, for married respondents, received any income from this source during the previous calendar year.

Demographics, education, and marital status: The analysis also includes controls for respondent age, race (white, black, other), ethnicity (Hispanic/not Hispanic), marital status, gender, and years of education.

\section{A. Descriptive results}

Table 1 presents basic descriptive statistics on the sample. Statistics are presented for the whole sample and also for those with family income less than 175 percent of poverty, corresponding roughly to the lowest quartile of income, and for those with family income greater than 500 percent of poverty, corresponding roughly to the highest quartile. Overall, ten percent of the elderly report some hardship. Seven percent report medication cutbacks, four percent report food cutbacks, and one percent actually skipped meals. Seven percent of the sample lives in poverty and nearly a quarter lives in a family with income less than 175 percent of the Federal poverty level. Ten percent of the sample uses Medicaid, Food Stamps, or SSI (or some combination of the three programs).

Table 2 examines in more detail the relationship between income and different hardships. Panel A of Table 2 shows that the prevalence of different hardships declines as income increases; Figure 1 shows the same information graphically. While there is a strong relationship between income and hardship at low levels of income, at some point the relationship flattens out; additional income above this level does nothing to reduce hardship. This non-linear relationship between income and hardship is not particularly surprising; what is surprising is how high income must be before additional income is no longer associated with lower hardship. Income must be about five times the poverty level before its effect on the probability of reporting any 
hardship fades out. This is driven mostly by medication cutbacks; the income gradients in food cutbacks and skipped meals fade out earlier (at about four and 3.5 times the poverty level, respectively).

Also surprising is the fact that even at the highest levels of income, the prevalence of hardship is not zero. Even in families with incomes greater than five times the poverty level, about five percent of elderly individuals experience some hardship. Hardship at higher levels of income consists mostly of medication cutbacks; only one or two percent of these individuals have cut back on food, and skipping meals is essentially unknown among families with income greater than three times the poverty level.

Panel B of Table 2 presents the cumulative distribution of elderly individuals experiencing hardship by family income relative to poverty. Eighty percent of the elderly experiencing hardship are not poor. In other words, although Panel A establishes that hardship is more likely for the poor, Panel B shows that most people of the elderly experiencing hardship are not poor. Indeed, just over half (52 percent) live in families with incomes above 175 percent of the poverty level and so are very unlikely to be eligible for any transfer programs that might mitigate hardships.

The role of transfer programs is particularly interesting because of the suggestion in the existing literature that hardships are more likely among recipients than among eligible nonrecipients. In particular, a number of studies (most recently Haider, Jacknowitz and Schoeni [2003] and Wilde and Nord [2005], who review the earlier literature on this topic) document that food insecurity is more prevalent among Food Stamp recipients than among non-recipients. Table 3 explores the use of three programs - Food Stamps, Medicaid, and SSI - as a function of income and presents the probability of hardship, conditional on income, for program users and 
non-users. The first panel of Table 3 confirms that, consistent with the results cited above, foodrelated hardship is more likely among those who receive Food Stamps than among those who do not, conditioning for income category. The next panel shows that this result does not hold for medication cutbacks and Medicaid recipiency; within an income category, those covered by Medicaid are less likely to report cutting back on medications than those who do not have Medicaid. Results for any hardship and SSI income in the next panel are ambiguous. Overall, looking at any hardship and take-up of any of the three programs, hardship is higher among those receiving any benefits than among those who receive none (bottom panel of Table 3 ). That is, the overall pattern looks more like what is observed for Food Stamps than for Medicaid. Of course, these patterns do not imply a causal relationship between use of a particular program and hardship; in addition to the fact that these simple tables control for no covariates other than very broad income categories, even estimates from multivariate models likely suffer from selection on unobservable characteristics (as discussed in Haider et al. [2003] and Wilde and Nord [2005]) so that the partial correlation between program use and hardship reflects both self-selection into program use and any causal effect of program use on hardship, which likely go in different directions.

Table 4 explores the relationship between hardship and failure to take up transfer programs further by presenting the cumulative distribution of the elderly experiencing poverty by income (collapsed into two categories: greater than or less than 175 percent of poverty) and the use of transfer programs (Food Stamps, Medicaid, and SSI income). As already noted, about half of those experiencing hardship fall into the higher income category; about ten percent of these (or five percent of the total) are programs users. In the lower-income group, most of those experiencing hardship are not program users. Overall, 28 percent of those experiencing hardship 
are low-income individuals failing to take up any public programs; this suggests that the potential to mitigate hardship through improved outreach alone, without also expanding eligibility or increasing benefits, is limited.

Thus, the main result from this descriptive analysis is that while hardship is more likely among those with lower incomes and among those who use public programs, only 20 percent of the elderly who experience hardship are low-income program users. Why are so many non-poor elderly experiencing hardship? What other characteristics besides income predict hardship? I turn next to multivariate models that will address these questions.

\section{B. Multivariate results}

I use the 2006 HRS data to estimate multivariate linear probability models predicting hardship as a function of demographics, health, and cognition. The model is estimated separately for three outcomes: any hardship, food cutbacks, and medication cutbacks. All models include the following explanatory variables: age, years of education, race/ethnicity dummies, gender and marital status, self-rated health, Nagi limitations, memory score, Serial Sevens score, and a dummy for employment at the time of the survey. ${ }^{4}$ In addition, I estimate models with and without controls for income. More specifically, for each outcome, I estimate three specifications: one does not include any controls for family income, the second includes $\ln$ (family income) as a control, and the third includes a set of five dummies reflecting six categories of family income relative to poverty: $101-200 \%, 201-300 \%, 301-400 \%, 401-800 \%$, and greater than $800 \%$ (the omitted category is less than or equal to $100 \%$ ). These different specifications allow me to understand both the "shape" of the marginal effect of income on hardship - after controlling for other factors, does the impact of income on hardship fade out at high levels of income as

\footnotetext{
${ }^{4}$ The models reported here are parsimonious ones in which most variables (e.g. education, cognition, and health stauts) are entered linearly; more flexible models that include these variables as vectors of categorical dummies yield results that are qualitatively very similar to the parsimonious models.
} 
suggested by Figure 1? - and also, by comparing the coefficients from the models with and without income controls, to understand the extent to which the apparent effect of other covariates such as education on hardship are in fact income effects.

Table 5 presents the multivariate results. The most striking predictors of hardship are measures of poor health, as She and Livermore (2007) found for the non-elderly population and Lee and Frongillo (2001) report for food insecurity among the elderly. Table 5 shows that among the elderly, each one-point increase on a scale where one represents excellent health and 5 represents poor health increases the probability of hardship by about two percentage points. This effect is consistent for both types of cutback, food and medication, and is not significantly affected by the inclusion of controls for income. Each additional physical limitation on the twelve-point Nagi scale also increases the probability of hardship by about a percentage point, and again this effect is consistent across models. In particular, this effect is not driven by lower income among individuals in poorer health; the inclusion of income controls affects the coefficients on Nagi limitations very little.

There are two likely stories to explain why poorer health means increased hardship. One is inefficient home production: it is simply harder to get by if you are in poor health, and in particular it is hard to make do with less. For example, activity limitations might require an elderly person to purchase prepared meals rather than cooking from scratch, to shop at expensive convenience stores rather than shopping around for lower prices, etc. Another explanation is that the burden of out-of-pocket spending for medical care reduces resources available for food and medicine; this is the notion underlying criticisms of the fact that the official poverty measure does not take out-of-pocket medical spending into account. While further research will be necessary to determine the relative importance of these two stories, two pieces of circumstantial 
evidence point toward the latter. The first is that there is no significant effect of lower cognitive ability on hardship, even though this, too, should make getting by more difficult. Second, as shown in Figure 2, out-of-pocket medical care spending is higher among the high-income elderly who experience hardship compared to those with similar income who do not experience hardship.

In all models, older individuals are less likely to report hardship. Haider, Jacknowitz and Schoeni (2003) report a similar finding for food-related hardship (skipped meals) and speculate that this may be due to the well-established fact that caloric needs decline with age among the elderly. On the other hand, a similar story cannot explain why medication cutbacks also decline with age, since medication use increases with age.

More education reduces the probability of hardship; about half of this effect operates through income, overall and for food cutbacks, while all of the apparent effect of education on medication cutbacks is due to the correlation between education and income. Somewhat surprisingly, cognitive ability - measured using either memory score or "Serial Sevens" score is not an independent predictor of hardship, as already noted.

Blacks have significantly higher rates of food cutbacks but not medication cutbacks; rates for other nonwhites and Hispanics are similar to those for white non-Hispanics (the omitted group). Unmarried women, three-quarters of whom are widows, report significantly higher rates of hardship than do single men, married men, or married women; much of this effect is due to their lower incomes. Work does not significantly affect the probability of reported hardship, when income is controlled for flexibly (i.e. using a set of dummies).

Not surprisingly, more income means less hardship. Coefficients from the models with $\ln ($ income $)$ entered linearly suggest that a one-point increase in $\ln ($ income $)$ - which corresponds 
roughly to doubling income - reduces the probability of any hardship by about 5 percentage points, with a significant 2 to 3 percentage point effect on each of the two hardships. Coefficients from models with income entered as a set of dummies reflecting family income relative to poverty (below poverty is the omitted category) suggest that the "shape" of the hardship/income relationship is more or less what was shown in Figure 1. That is, more income means less hardship, up to a point - the effect in the multivariate models flattens out at above about 300 percent of poverty for either hardship, 200 percent of poverty for food cutbacks, and 400 percent of poverty for medication cutbacks (all slightly lower thresholds than the ones suggested by Figure 1).

\section{Individual fixed effects estimates}

In order to address at least partially the concern that unmeasured individual-level factors correlated with the explanatory variables may actually be causing hardship, I also estimate models with an individual fixed effect (FE). In order to do this I augment the 2006 data used in the analysis so far with data from the 2004 wave of the HRS. This means I lose 468 individuals who appeared in the 2006 survey wave but were not in $2004 .{ }^{5}$ The FE models reported in Table 6 confirm the central finding of the OLS models reported in Table 6: health (whether selfreported general health status or Nagi limitations) is an important predictor of hardship. The magnitude of the FE estimates is smaller than the OLS estimates - about one-third to one-half the size of those effects - but still significant. Other explanatory variables such as marital status and income that were significant in OLS models are no longer significant in the FE models, although it is difficult to say with certainty whether this is because these variables truly do not

\footnotetext{
${ }^{5}$ OLS models like those in Table 5 estimated on the smaller sample that is used in the FE analysis yield results almost identical to those in Table 5, suggesting that the slight change in sample composition is not responsible for any difference between the results in Tables 5 and 6 .
} 
matter in determining hardship or because there is not much change in these characteristics over the two-year window from 2004 to 2006.

\section{Models including program take-up}

What about the relationship between program take-up and hardship in multivariate models? As discussed above, it is likely that this relationship is driven by selection on unobservables, even in FE models (as in Wilde and Nord [2005]). Nonetheless, augmenting the OLS models with dummies reflecting the use of transfer programs (full results are not reported here) generally confirms the findings of Table 4 . That is, the multivariate results confirm that food cutbacks, but not medication cutbacks, are more likely among those who use public programs; the overall effect of program use on "any hardship" is positive and significant in OLS models, with a magnitude of about 8 percentage points. In FE models, the program use dummies are generally small, negative, and insignificant. An exception is that I find a positive but insignificant effect of Food Stamp take-up on food cutbacks; Wilde and Nord (2005) found a positive and significant effect in this case.

\section{Discussion}

The empirical analysis in this paper yields two important results with implications for public policy and future research. First, I find that while hardship is more likely among poor individuals and, to some extent, among poor individuals who are already users of transfer programs, the majority of the elderly experiencing hardship are neither poor nor using any of these programs. This means that the impact of efforts to reduce hardship through increased outreach and enrollment among eligible non-participants, or by increasing benefit levels for those who already participate, is necessarily limited. Finding ways to target transfer programs more precisely to those experiencing hardship - which probably involves re-writing the 
eligibility rules for the programs - could also be an important component of efforts to reduce hardship among the elderly.

Second, like a number of earlier studies cited above, I find that health status is an important predictor of hardship among the elderly: individuals in worse self-reported health or who report more limitations on physical activity are significantly more likely to experience hardship. This result holds whether or not income is included as a control in the models and is robust to the inclusion of individual fixed effects. The importance of poor health in predicting hardship supports the view implicit in the criticisms of the official poverty measure that high medical spending may effectively reduce the resources available to some apparently high-income households, placing them at risk of hardship. One way to address this problem directly regardless of any methodological changes in the measurement of poverty - would be for Medicaid and SSI eligibility rules to allow the deduction of some or all out-of-pocket medical spending from countable income for elderly beneficiaries, as the Food Stamp program currently does for applicants ages 60 and older. Further research is needed to estimate whether this change, combined with take-up of benefits among those newly eligible for them, would significantly reduce hardship among the elderly. 


\section{References}

Beverly, Sondra. 2000. Using measures of material hardship to assess well-being. Focus, Institute for Research on Poverty, 21(2): 65 - 69.

Bound, John, Duncan G. J., Laren D. S., and Oleinick L. 1991. Poverty dynamics in widowhood. Journal of Gerontology 46:S115-S124.

Brady, David. 2004. Reconsidering the divergence between elderly, child, and overall poverty. Research on Aging 26: 487 - 510.

Butrica, Barbara A., Dan Murphy and Sheila R. Zedlewski. 2007. How many struggle to get by in retirement? Center for Retirement Research Working Paper 2007-27.

Charles, Kerwin Kofi, Sheldon Danziger, Laurie Pounder and Robert F. Schoeni. 2006. Consumption, income, and well-being among the mature population. Manuscript, National Poverty Center, University of Michigan.

Citro, Constance M. and Robert T. Michael. 1995. Measuring Poverty: A New Approach. Washington, DC: National Academies Press.

Danziger, S., M. Corcoran, S. K. Danziger, and C. Heflin. 2000. Work, income and material hardship after welfare reform. Journal of Consumer Affairs 34 (1): 6-30

DeNavas-Walt, Carmen, Bernadette D. Proctor, and Jessica C. Smith. 2009. Income, poverty and health insurance coverage in the United States: 2008. U.S. Census Bureau, Current Population Reports, P60-236.

Engelhardt, Gary V. and Jonathan Gruber. 2006. Social Security and the evolution of elderly poverty. Appearing in: Auerbach, Alan, David Card and John Quigley (eds.), Public Policy and the Income Distribution. New York: Russell Sage Foundation.

Engelhardt, Gary V., Jonathan Gruber, and Cynthia D. Perry. 2005. Social Security and elderly living arrangements: Evidence from the Social Security notch. Journal of Human Resources 40(2): 354-372.

Federman, Maya, Thesia I. Garner, Kathleen Short, W. Boman Cutter IV, John Kiely, David Levine, Duane McGough, and Marilyn McMillen. 1996. What does it mean to be poor in America? Monthly Labor Review May: 3 - 17.

Fonda, Stephanie and A. Regula Herzog. 2004. Documentation of physical functioning measures in the Health and Retirement Study and the Asset and Health Dynamics among the Oldest Old Study. HRS Documentation Report DR-008.

Gillen, Martie and Hyungsoo Kim. 2009. Older women and poverty transition: Consequences of income source changes from widowhood. Journal of Applied Gerontology 28: 320 - 341. 
Haider, Steven J., Alison Jacknowitz and Robert F. Schoeni. 2003. Food Stamps and the elderly: Why is participation so low? Journal of Human Resources 38(S): 1080-1111.

Haveman, Robert, Karen Holden, Kathryn Wilson, and Barbara Wolfe. 2003. Social Security, age of retirement, and economic well-being: Intertemporal and demographic patterns among retired-worker beneficiaries. Demography 40(2): 369-394.

Haveman, Robert, Karen Holden, Barbara Wolfe, and A. Romanov. 2007. Assessing the maintenance of savings sufficiency over the first decade of retirement. International Tax and Public Finance 14:481-502.

Haveman, Robert., Karen Holden, Barbara Wolfe, and S. Sherlund. 2006. Do newly retired workers in the United States have sufficient resources to maintain well-being? Economic Inquiry 44: 249-64.

Heisler, Michele, Todd H. Wagner, and John D. Piette. 2005. Patient strategies to cope with high prescription medication costs: who is cutting back on necessities, increasing debt, or underusing medications? Journal of Behavioral Medicine 28(1): 43 - 51.

Hungerford, Thomas L. 2001. The economic consequences of widowhood on elderly women in the United States and Germany. The Gerontologist 41:103-110.

Hurd, Michael D. and Susann Rohwedder. 2006a. Alternative measures of replacement rates. Michigan Retirement Research Center Working Paper 2006-132.

Hurd, Michael D. and Susann Rohwedder. 2006b. Economic well-being at older ages: Incomeand consumption-based poverty measures in the HRS. National Bureau of Economic Research Working Paper 12680.

Hurd, Michael D. and Susann Rohwedder. 2008a. Adequacy of economic resources in retirement and returns-to-scale in consumption. Michigan Retirement Research Center Research Paper 2008-174.

Hurd, Michael D. and Susann Rohwedder. 2008b. The adequacy of economic resources in retirement. Michigan Retirement Research Center Research Paper 2008-184.

Lee, Jung Sun and Edward A. Frongillo, Jr. 2001. Factors associated with food insecurity among U.S. elderly persons: Importance of functional impairments. Journal of Gerontology: Social Sciences 56B(2): S94-S99.

Levy, Helen and David R. Weir. 2007. Take-up of Medicare Part D and the SSA subsidy: Early results from the Health and Retirement Study. Michigan Retirement Research Center Working Paper 2007-163. 
Mayer, Susan E. and Christopher Jencks. 1989. Poverty and the distribution of material resources. Journal of Human Resources, 24:88-114.

McGarry, Kathleen. 1995. Measurement error and poverty rates of widows. Journal of Human Resources 30(1): 113-134.

McGarry, Kathleen and Robert F. Schoeni. 2005. Widow(er) poverty and out-of-pocket medical expenditures near the end of life. Journal of Gerontology: Social Sciences 60B(3): S160S168.

Johnson, Richard W. and Gordon B.T. Mermin. 2009. Financial hardship before and after Social Security's eligibility age. Washington, DC: The Urban Institute.

Meyer, Bruce D. and James X. Sullivan. 2003. Measuring the well-being of the poor using income and consumption. Journal of Human Resources 38(S) 1180-1220.

Mitchell, Olivia S. and J. F. Moore. 1998. Can Americans afford to retire? New evidence on retirement saving adequacy. Journal of Risk and Insurance 65(3): 371-400.

Ofstedal, Mary Beth, Gwenith G. Fisher and A. Regula Herzog. 2005. Documentation of cognitive functioning measures in the Health and Retirement Study. HRS Documentation Report DR-006.

Oullette, Tammy, Nancy Burstein, David Long, and Erik Beecroft. 2004. Measures of material hardship. Final report to the U.S. Department of Health and Human Services.

Piette, John D., Michele Heisler, and Todd H. Wagner. 2004. Cost-related medication underuse among chronically ill adults: The treatments people forgo, how often, and who is at risk. Am J Public Health 94:1782-1787.

Rector, Robert E., Kirk A. Johnson, and Sarah E. Youssef. 1999. The extent of material hardship and poverty in the United States. Review of Social Economy 57(3): $351-387$.

Scholz, Karl, Ananth Seshadri and Surachai Khitatrakun. 2006. Are Americans saving 'optimally' for retirement?' Journal of Political Economy 114(4):607-643.

Sevak, Purvi, David R. Weir, and Robert J. Willis. 2003/2004. The economic consequences of a husband's death: Evidence from the HRS and AHEAD. Social Security Bulletin 65(3): $31-44$.

She, Peiyun and Gina A. Livermore. 2007. Material hardship, poverty, and disability among working-age adults. Social Science Quarterly 88(4): 970 - 989.

Short, Kathleen and Thesia I. Garner. 2002. Experimental poverty measures: accounting for medical expenditures. Monthly Labor Review August: 3 - 13. 
Skinner, Jonathan. 2007. Are you sure you're saving enough for retirement? Journal of Economic Perspectives 21(3): $59-80$.

Steinman, Michael A., Laura P. Sands, and Kenneth E. Covinsky. 2001. Self-restriction of medications due to cost in seniors without prescription coverage. Journal of General Internal Medicine 16: 793-799.

Vanderhei, Jack. 1994. Measuring retirement income adequacy, part one: Traditional replacement ratios and results for workers at large companies. EBRI Notes 25(9): 2-12.

Weir, David R. and Robert J. Willis. 2000. Prospects for widow poverty. Appearing in Mitchell, Olivia S. Mitchell, P. Brett Hammond, Anna M. Rappaport (eds.), Forecasting Retirement Needs and Retirement Wealth. Philadelphia: University of Pennsylvania Press.

Wilde, Parke and Mark Nord. 2005. The effect of Food Stamps on food security: A panel data approach. Review of Agricultural Economics 27(3): 425-432.

Zick, Cathleen D. and Karen Holden. 2000. An assessment of the wealth holdings of recent widows. Journal of Gerontology: Social Sciences 55B (2): S90-S97. 
Table 1

Sample means

Source: Health and Retirement Study, 2006

\begin{tabular}{lrrr}
\hline & Foll sample & $\begin{array}{r}\text { Low } \\
\leq 175 \% \text { FPL }\end{array}$ & $\begin{array}{r}\text { High income: } \\
>500 \% \text { FPL }\end{array}$ \\
\hline Any hardship & 0.101 & 0.200 & 0.042 \\
Food cutbacks & 0.042 & 0.106 & 0.016 \\
Skipped meals & 0.016 & 0.049 & 0.003 \\
Medication cutback & 0.070 & 0.126 & 0.028 \\
\hline Age & 75.0 & 76.6 & 73.2 \\
Years of education & 13.1 & 12.2 & 14.0 \\
Memory score (0-20) & 9.0 & 7.8 & 10.0 \\
Serial sevens score (0-4) & 2.5 & 1.9 & 2.9 \\
Unmarried male & 0.114 & 0.144 & 0.106 \\
Unmarried female & 0.332 & 0.553 & 0.189 \\
Married male & 0.314 & 0.164 & 0.418 \\
Married female & 0.241 & 0.139 & 0.287 \\
Black & 0.078 & 0.147 & 0.046 \\
Nonwhite & 0.097 & 0.177 & 0.066 \\
Hispanic & 0.054 & 0.112 & 0.022 \\
Self-rated health & & & \\
(1=excellent, 5=poor) & 2.9 & 3.4 & 2.6 \\
No. of physical limitations (0-12) & 4.4 & 5.7 & 3.4 \\
Working? & 0.147 & 0.046 & 0.273 \\
Family income (2005) & $\$ 40,588$ & $\$ 11,305$ & $\$ 86,539$ \\
Family income/poverty & 4.6 & 1.2 & 10.0 \\
Family income $<$ poverty & 0.074 & 0.307 & 0.000 \\
Family income $<175 \%$ FPL & 0.242 & 0.000 & 0.000 \\
Any transfer program use & 0.097 & 0.213 & 0.019 \\
$\quad$ Medicaid & 0.071 & 0.143 & 0.012 \\
$\quad$ Food Stamps & 0.045 & & 0.006 \\
SSI & 0.038 & & 0.009 \\
Sample n & 10,900 & & 3,177 \\
\hline
\end{tabular}


Table 2

Prevalence of material hardship among the elderly $(65+)$

Source: Health and Retirement Study, 2006

\begin{tabular}{|c|c|c|c|c|}
\hline & \multicolumn{4}{|c|}{$\begin{array}{c}\text { Panel A } \\
\text { Fraction reporting hardship }\end{array}$} \\
\hline & $\begin{array}{c}\text { Any } \\
\text { hardship }\end{array}$ & $\begin{array}{l}\text { Food } \\
\text { cutback }\end{array}$ & $\begin{array}{c}\text { Skipped } \\
\text { meals }\end{array}$ & $\begin{array}{c}\text { Medication } \\
\text { cutback }\end{array}$ \\
\hline \multicolumn{5}{|c|}{ Family income relative to poverty: } \\
\hline$\leq 75 \%$ & 0.257 & 0.151 & 0.087 & 0.134 \\
\hline $76-100 \%$ & 0.250 & 0.167 & 0.072 & 0.132 \\
\hline $101-125 \%$ & 0.183 & 0.092 & 0.040 & 0.120 \\
\hline $126-150 \%$ & 0.189 & 0.091 & 0.042 & 0.129 \\
\hline $151-175 \%$ & 0.157 & 0.065 & 0.024 & 0.120 \\
\hline $176-200 \%$ & 0.108 & 0.034 & 0.020 & 0.079 \\
\hline $201-250 \%$ & 0.113 & 0.037 & 0.016 & 0.088 \\
\hline $251-300 \%$ & 0.083 & 0.027 & 0.007 & 0.062 \\
\hline $301-350 \%$ & 0.074 & 0.019 & 0.000 & 0.058 \\
\hline $351-400 \%$ & 0.064 & 0.012 & 0.002 & 0.054 \\
\hline $401-450 \%$ & 0.061 & 0.016 & 0.000 & 0.054 \\
\hline $451-500 \%$ & 0.037 & 0.020 & 0.005 & 0.022 \\
\hline $501-600 \%$ & 0.051 & 0.016 & 0.002 & 0.037 \\
\hline $601-700 \%$ & 0.034 & 0.008 & 0.004 & 0.028 \\
\hline $701-800 \%$ & 0.059 & 0.028 & 0.001 & 0.035 \\
\hline \multirow[t]{2}{*}{$>800 \%$} & 0.037 & 0.014 & 0.002 & 0.024 \\
\hline & \multicolumn{4}{|c|}{$\begin{array}{c}\text { Panel B } \\
\text { CDF of individuals reporting hardship }\end{array}$} \\
\hline$\leq 75 \%$ & 0.079 & 0.111 & 0.167 & 0.059 \\
\hline $76-100 \%$ & 0.187 & 0.283 & 0.360 & 0.141 \\
\hline $101-125 \%$ & 0.284 & 0.398 & 0.493 & 0.233 \\
\hline $126-150 \%$ & 0.393 & 0.523 & 0.644 & 0.340 \\
\hline $151-175 \%$ & 0.482 & 0.611 & 0.728 & 0.438 \\
\hline $176-200 \%$ & 0.541 & 0.656 & 0.795 & 0.500 \\
\hline $201-250 \%$ & 0.661 & 0.749 & 0.899 & 0.636 \\
\hline $251-300 \%$ & 0.740 & 0.810 & 0.941 & 0.720 \\
\hline $301-350 \%$ & 0.802 & 0.849 & 0.943 & 0.790 \\
\hline $351-400 \%$ & 0.843 & 0.867 & 0.951 & 0.839 \\
\hline $401-450 \%$ & 0.874 & 0.886 & 0.951 & 0.877 \\
\hline $451-500 \%$ & 0.892 & 0.909 & 0.966 & 0.893 \\
\hline $501-600 \%$ & 0.924 & 0.933 & 0.972 & 0.927 \\
\hline $601-700 \%$ & 0.939 & 0.941 & 0.983 & 0.944 \\
\hline $701-800 \%$ & 0.959 & 0.964 & 0.986 & 0.961 \\
\hline$>800 \%$ & 1.000 & 1.000 & 1.000 & 1.000 \\
\hline
\end{tabular}

Note: Unweighted sample size is 10,900 , 
Table 3

Transfer program use and the probability of hardship

Source: Health and Retirement Study, 2006

\begin{tabular}{|c|c|c|c|}
\hline \multirow[t]{2}{*}{ Income/FPL: } & \multirow[b]{2}{*}{$\operatorname{Pr}($ Food Stamps $)$} & \multicolumn{2}{|c|}{$\operatorname{Pr}($ food cutbacks $)$} \\
\hline & & Food Stamps $=0$ & Food Stamps $=1$ \\
\hline$\leq 75 \%$ & 0.258 & 0.081 & 0.352 \\
\hline $76-100 \%$ & 0.327 & 0.120 & 0.264 \\
\hline $101-125 \%$ & 0.128 & 0.072 & 0.225 \\
\hline $126-150 \%$ & 0.059 & 0.081 & 0.257 \\
\hline $151-175 \%$ & 0.040 & 0.052 & 0.366 \\
\hline \multirow[t]{3}{*}{$>175 \%$} & 0.014 & 0.020 & 0.169 \\
\hline & & \multicolumn{2}{|c|}{$\operatorname{Pr}(\mathrm{Rx}$ cutbacks $)$} \\
\hline & $\operatorname{Pr}($ Medicaid) & Medicaid $=0$ & Medicaid $=1$ \\
\hline$\leq 75 \%$ & 0.372 & 0.154 & 0.100 \\
\hline $76-100 \%$ & 0.432 & 0.146 & 0.114 \\
\hline $101-125 \%$ & 0.229 & 0.134 & 0.073 \\
\hline $126-150 \%$ & 0.094 & 0.127 & 0.155 \\
\hline $151-175 \%$ & 0.065 & 0.119 & 0.135 \\
\hline \multirow[t]{3}{*}{$>175 \%$} & 0.026 & 0.050 & 0.114 \\
\hline & & \multicolumn{2}{|c|}{ Pr(any hardship) } \\
\hline & $\operatorname{Pr}$ (any SSI income) & SSI income $=0$ & $\mathrm{SSI}$ income $=1$ \\
\hline$\leq 75 \%$ & 0.189 & 0.261 & 0.241 \\
\hline $76-100 \%$ & 0.271 & 0.208 & 0.366 \\
\hline $101-125 \%$ & 0.117 & 0.181 & 0.198 \\
\hline $126-150 \%$ & 0.056 & 0.176 & 0.404 \\
\hline $151-175 \%$ & 0.028 & 0.147 & 0.502 \\
\hline \multirow[t]{3}{*}{$>175 \%$} & 0.012 & 0.068 & 0.148 \\
\hline & & \multicolumn{2}{|c|}{ Pr(any hardship) } \\
\hline & $\operatorname{Pr}$ (any program use) & Program use $=0$ & Program use $=1$ \\
\hline$\leq 75 \%$ & 0.472 & 0.211 & 0.308 \\
\hline $76-100 \%$ & 0.542 & 0.172 & 0.316 \\
\hline $101-125 \%$ & 0.289 & 0.152 & 0.261 \\
\hline $126-150 \%$ & 0.140 & 0.161 & 0.358 \\
\hline $151-175 \%$ & 0.091 & 0.142 & 0.313 \\
\hline$>175 \%$ & 0.039 & 0.064 & 0.175 \\
\hline
\end{tabular}

Note: Unweighted sample size for each panel is 10,900 individuals. 
Table 4

Who experiences hardship?

Distribution of the elderly experiencing hardship by family income and use of transfer programs Source: Health and Retirement Study, 2006

\begin{tabular}{ll} 
Low income, program user (Medicaid, Food Stamps, or SSI) & 0.204 \\
Low income, no program use & 0.278 \\
Not low income, program user & 0.052 \\
Not low income, no program use & 0.466 \\
\hline Total & 1.000 \\
\hline
\end{tabular}

Notes:

Unweighted sample size $=10,900$

Low income is defined as having family income $\leq 175 \%$ of the poverty level. 
Table 5

Multivariate models predicting hardship among the elderly

Full sample, OLS estimates

Source: Health and Retirement Study, 2006

\begin{tabular}{|c|c|c|c|c|c|c|c|c|c|}
\hline & \multicolumn{3}{|c|}{ Either hardship } & \multicolumn{3}{|c|}{ Food cutbacks } & \multicolumn{3}{|c|}{ Medication cutbacks } \\
\hline & $(1)$ & $(2)$ & (3) & (4) & $(5)$ & (6) & $(7)$ & $(8)$ & (9) \\
\hline Age & $\begin{array}{l}-0.006 \\
(0.000)^{* *}\end{array}$ & $\begin{array}{l}-0.006 \\
(0.000)^{* *}\end{array}$ & $\begin{array}{l}-0.006 \\
(0.000)^{* *}\end{array}$ & $\begin{array}{l}-0.002 \\
(0.000)^{* *}\end{array}$ & $\begin{array}{l}-0.002 \\
(0.000)^{* *}\end{array}$ & $\begin{array}{l}-0.002 \\
(0.000)^{* *}\end{array}$ & $\begin{array}{l}-0.004 \\
(0.000)^{* *}\end{array}$ & $\begin{array}{l}-0.004 \\
(0.000)^{* *}\end{array}$ & $\begin{array}{l}-0.004 \\
(0.000)^{* *}\end{array}$ \\
\hline $\begin{array}{l}\text { Self-rated health } \\
(1=\text { ex., } 5=\text { poor })\end{array}$ & $\begin{array}{c}0.020 \\
(0.003)^{* *}\end{array}$ & $\begin{array}{c}0.017 \\
(0.003)^{* *}\end{array}$ & $\begin{array}{c}0.017 \\
(0.003)^{* *}\end{array}$ & $\begin{array}{l}0.008 \\
(0.002)^{* *}\end{array}$ & $\begin{array}{l}0.006 \\
(0.002)^{* *}\end{array}$ & $\begin{array}{l}0.006 \\
(0.002)^{* *}\end{array}$ & $\begin{array}{l}0.015 \\
(0.003)^{* *}\end{array}$ & $\begin{array}{l}0.013 \\
(0.003)^{* *}\end{array}$ & $\begin{array}{l}0.014 \\
(0.003)^{* *}\end{array}$ \\
\hline $\begin{array}{l}\text { Nagi limitations } \\
(0-12)\end{array}$ & $\begin{array}{c}0.014 \\
(0.001)^{* *}\end{array}$ & $\begin{array}{c}0.013 \\
(0.001)^{* *}\end{array}$ & $\begin{array}{c}0.013 \\
(0.001)^{* *}\end{array}$ & $\begin{array}{l}0.006 \\
(0.001)^{* *}\end{array}$ & $\begin{array}{l}0.006 \\
(0.001)^{* *}\end{array}$ & $\begin{array}{l}0.006 \\
(0.001)^{* *}\end{array}$ & $\begin{array}{l}0.011 \\
(0.001)^{* *}\end{array}$ & $\begin{array}{l}0.010 \\
(0.001)^{* *}\end{array}$ & $\begin{array}{l}0.010 \\
(0.001)^{* *}\end{array}$ \\
\hline Years of education & $\begin{array}{l}-0.006 \\
(0.001)^{* *}\end{array}$ & $\begin{array}{l}-0.003 \\
(0.001)^{*}\end{array}$ & $\begin{array}{l}-0.003 \\
(0.001)^{* *}\end{array}$ & $\begin{array}{l}-0.004 \\
(0.001)^{* *}\end{array}$ & $\begin{array}{l}-0.002 \\
(0.001)^{* *}\end{array}$ & $\begin{array}{l}-0.002 \\
(0.001)^{* *}\end{array}$ & $\begin{array}{l}-0.004 \\
(0.001)^{* *}\end{array}$ & $\begin{array}{l}-0.001 \\
(0.001)\end{array}$ & $\begin{array}{l}-0.002 \\
(0.001)\end{array}$ \\
\hline $\begin{array}{l}\text { Memory score } \\
(0-20)\end{array}$ & $\begin{array}{c}0.001 \\
(0.001)\end{array}$ & $\begin{array}{c}0.001 \\
(0.001)\end{array}$ & $\begin{array}{c}0.001 \\
(0.001)\end{array}$ & $\begin{array}{l}-0.000 \\
(0.001)\end{array}$ & $\begin{array}{l}-0.000 \\
(0.001)\end{array}$ & $\begin{array}{l}-0.000 \\
(0.001)\end{array}$ & $\begin{array}{c}0.001 \\
(0.001)\end{array}$ & $\begin{array}{c}0.001 \\
(0.001)\end{array}$ & $\begin{array}{c}0.001 \\
(0.001)\end{array}$ \\
\hline $\begin{array}{l}\text { Serial sevens score } \\
(0-5)\end{array}$ & $\begin{array}{l}-0.004 \\
(0.002)^{*}\end{array}$ & $\begin{array}{l}-0.003 \\
(0.002)\end{array}$ & $\begin{array}{l}-0.003 \\
(0.002)\end{array}$ & $\begin{array}{l}-0.003 \\
(0.001)^{*}\end{array}$ & $\begin{array}{l}-0.003 \\
(0.001)^{*}\end{array}$ & $\begin{array}{l}-0.002 \\
(0.001)\end{array}$ & $\begin{array}{l}-0.002 \\
(0.002)\end{array}$ & $\begin{array}{l}-0.001 \\
(0.002)\end{array}$ & $\begin{array}{l}-0.001 \\
(0.002)\end{array}$ \\
\hline Single female & $\begin{array}{c}0.049 \\
(0.007)^{* *}\end{array}$ & $\begin{array}{l}0.016 \\
(0.008)^{*}\end{array}$ & $\begin{array}{c}0.027 \\
(0.008)^{* *}\end{array}$ & $\begin{array}{c}0.011 \\
(0.005)^{*}\end{array}$ & $\begin{array}{l}-0.006 \\
(0.005)\end{array}$ & $\begin{array}{l}-0.004 \\
(0.005)\end{array}$ & $\begin{array}{l}0.046 \\
(0.006)^{* *}\end{array}$ & $\begin{array}{l}0.024 \\
(0.007)^{* *}\end{array}$ & $\begin{array}{l}0.034 \\
(0.007)^{* *}\end{array}$ \\
\hline Married female & $\begin{array}{c}0.014 \\
(0.008)\end{array}$ & $\begin{array}{c}0.013 \\
(0.008)\end{array}$ & $\begin{array}{c}0.013 \\
(0.008)\end{array}$ & $\begin{array}{l}-0.007 \\
(0.005)\end{array}$ & $\begin{array}{l}-0.007 \\
(0.005)\end{array}$ & $\begin{array}{l}-0.007 \\
(0.005)\end{array}$ & $\begin{array}{l}0.024 \\
(0.007)^{* *}\end{array}$ & $\begin{array}{l}0.023 \\
(0.007)^{* *}\end{array}$ & $\begin{array}{l}0.023 \\
(0.007)^{* *}\end{array}$ \\
\hline Single male & $\begin{array}{c}0.013 \\
(0.010)\end{array}$ & $\begin{array}{l}-0.006 \\
(0.010)\end{array}$ & $\begin{array}{c}0.001 \\
(0.010)\end{array}$ & $\begin{array}{l}-0.006 \\
(0.007)\end{array}$ & $\begin{array}{l}-0.015 \\
(0.007)^{*}\end{array}$ & $\begin{array}{l}-0.014 \\
(0.007)^{*}\end{array}$ & $\begin{array}{l}0.019 \\
(0.008)^{*}\end{array}$ & $\begin{array}{c}0.006 \\
(0.008)\end{array}$ & $\begin{array}{c}0.013 \\
(0.008)\end{array}$ \\
\hline Black & $\begin{array}{c}0.075 \\
(0.022)^{* *}\end{array}$ & $\begin{array}{c}0.072 \\
(0.022)^{* *}\end{array}$ & $\begin{array}{c}0.065 \\
(0.022)^{* *}\end{array}$ & $\begin{array}{l}0.063 \\
(0.015)^{* *}\end{array}$ & $\begin{array}{l}0.063 \\
(0.015)^{* *}\end{array}$ & $\begin{array}{l}0.055 \\
(0.015)^{* *}\end{array}$ & $\begin{array}{c}0.032 \\
(0.019)\end{array}$ & $\begin{array}{c}0.031 \\
(0.019)\end{array}$ & $\begin{array}{c}0.028 \\
(0.019)\end{array}$ \\
\hline Other nonwhite & $\begin{array}{c}0.022 \\
(0.020)\end{array}$ & $\begin{array}{c}0.016 \\
(0.020)\end{array}$ & $\begin{array}{c}0.017 \\
(0.020)\end{array}$ & $\begin{array}{c}0.013 \\
(0.014)\end{array}$ & $\begin{array}{c}0.008 \\
(0.014)\end{array}$ & $\begin{array}{c}0.007 \\
(0.014)\end{array}$ & $\begin{array}{c}0.008 \\
(0.017)\end{array}$ & $\begin{array}{c}0.004 \\
(0.017)\end{array}$ & $\begin{array}{c}0.007 \\
(0.017)\end{array}$ \\
\hline Hispanic & $\begin{array}{c}0.008 \\
(0.013)\end{array}$ & $\begin{array}{l}-0.006 \\
(0.013)\end{array}$ & $\begin{array}{l}-0.003 \\
(0.013)\end{array}$ & $\begin{array}{l}-0.001 \\
(0.009)\end{array}$ & $\begin{array}{l}-0.008 \\
(0.009)\end{array}$ & $\begin{array}{l}-0.012 \\
(0.009)\end{array}$ & $\begin{array}{c}0.005 \\
(0.011)\end{array}$ & $\begin{array}{l}-0.006 \\
(0.011)\end{array}$ & $\begin{array}{c}0.002 \\
(0.011)\end{array}$ \\
\hline
\end{tabular}

Table continues on next page. 
Table 5 (continued)

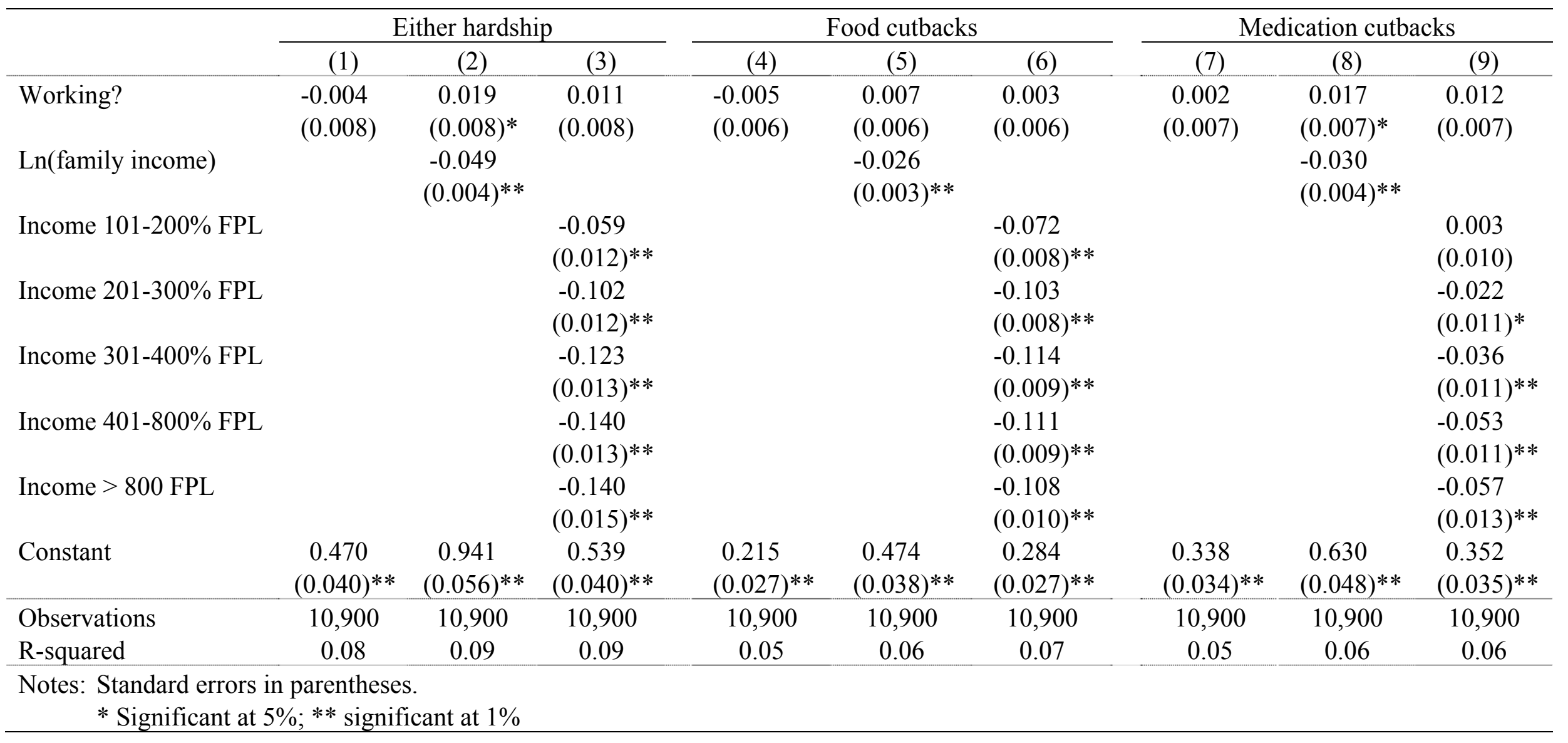


Table 6

Multivariate models predicting hardship among the elderly

Full sample, individual fixed effect estimates

Source: Health and Retirement Study, 2006

\begin{tabular}{llll}
\hline & $(1)$ & $(2)$ & $(3)$ \\
& $\begin{array}{l}\text { Either } \\
\text { hardship }\end{array}$ & $\begin{array}{l}\text { Food } \\
\text { cutbacks }\end{array}$ & $\begin{array}{l}\text { Medication } \\
\text { cutbacks }\end{array}$ \\
\hline Self-reported health & 0.008 & -0.001 & 0.012 \\
$(1=$ ex., 5=poor) & $(0.004)^{*}$ & $(0.003)$ & $(0.003)^{* *}$ \\
Nagi limitations & 0.004 & 0.003 & 0.003 \\
$(0-12)$ & $(0.002)^{*}$ & $(0.001)^{*}$ & $(0.001)^{*}$ \\
Memory score & 0.000 & 0.000 & -0.000 \\
$(0-20)$ & $(0.001)$ & $(0.001)$ & $(0.001)$ \\
Serial sevens score & 0.001 & -0.001 & 0.002 \\
$(0-5)$ & $(0.003)$ & $(0.002)$ & $(0.002)$ \\
Married & 0.029 & 0.038 & -0.009 \\
& $(0.027)$ & $(0.019) *$ & $(0.023)$ \\
Married*female & -0.036 & -0.029 & -0.009 \\
& $(0.035)$ & $(0.024)$ & $(0.029)$ \\
Working? & 0.001 & -0.004 & 0.004 \\
& $(0.011)$ & $(0.008)$ & $(0.009)$ \\
Ln(family income) & -0.004 & -0.000 & -0.004 \\
Constant & $(0.005)$ & $(0.003)$ & $(0.004)$ \\
& 0.091 & 0.023 & 0.071 \\
Observations & $(0.054)$ & $(0.038)$ & $(0.046)$ \\
Number of individuals & 21,064 & 21,064 & 21,064 \\
Standard errors in parentheses & 10,532 & 10,532 & 10,532 \\
* significant at 5\%; ** significant at $1 \%$ & & \\
\hline
\end{tabular}


Figure 1

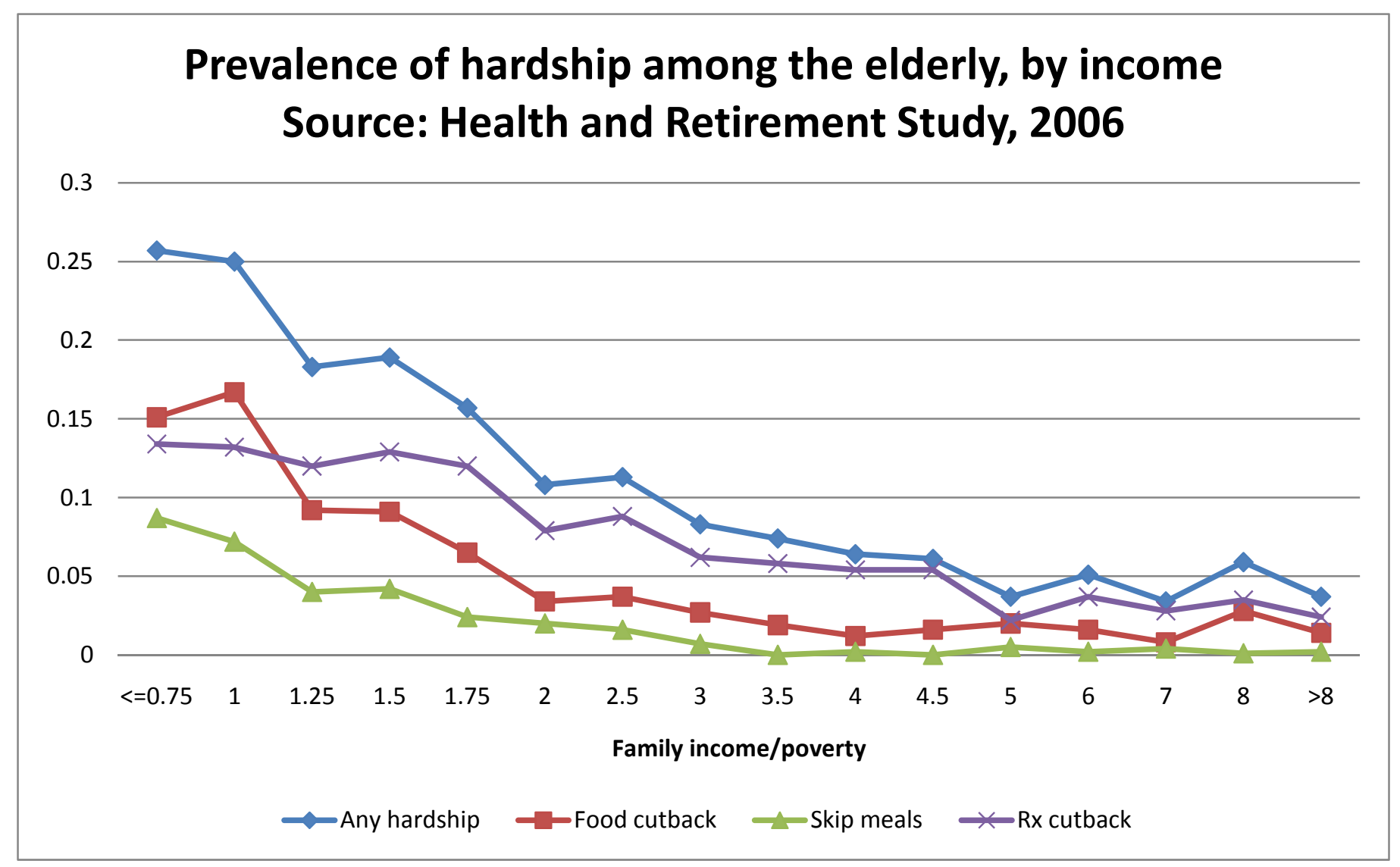


Figure 2

\section{Out-of-pocket medical spending, by income and hardship status Source: Health and Retirement Study, 2006}

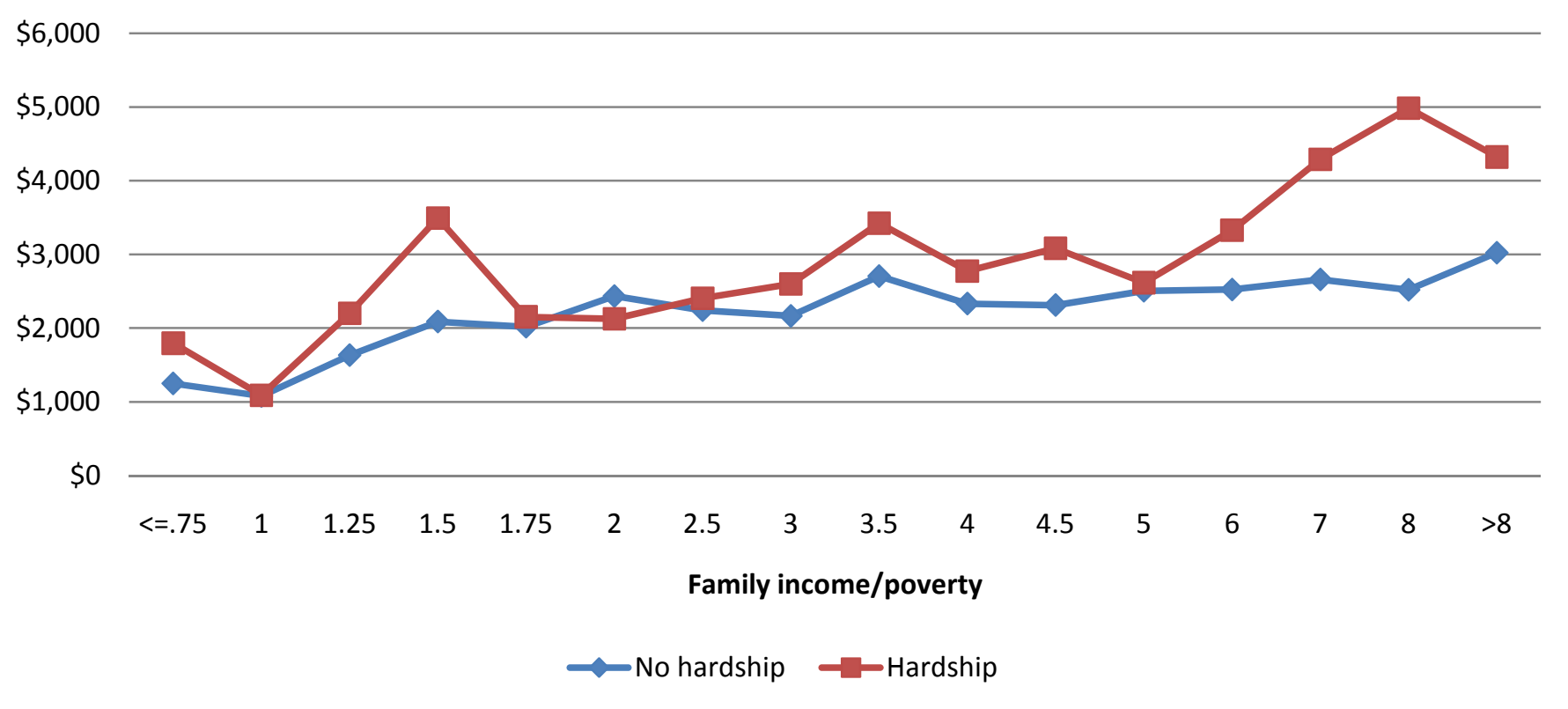

